\title{
Optimal breeding for a numerical improvement of sheep in the province of Maniema in the Democratic Republic of Congo
}

\author{
Francis Lunula Onakudu, ${ }^{1,}$, Nathan Utshudienyema Nyongombe ${ }^{1,3}$, Innocent Mwamba \\ Tshibangu ${ }^{1}$, Ngona Idi Abdallah ${ }^{4 *}$ \\ ${ }^{1}$ Research Unit in Nutrition, Animal Improvement and Agropastoralism, Faculty of Agronomic Sciences, \\ University of Lubumbashi, DR Congo \\ ${ }^{2}$ Faculty of Agronomic Sciences, University of Kindu, DR Congo \\ ${ }^{3}$ Faculty of Agronomic Sciences, National Pedagogical University of Kinshasa, DR Congo \\ ${ }^{4}$ Theriogenology Unit, Faculty of Veterinary Medicine, University of Lubumbashi, DR Congo \\ *jngona@yahoo.fr
}

Submitted on $24^{\text {th }}$ November 2021. Published online at www.m.elewa.org/journals/ on $31^{\text {st }}$ January 2022 https://doi.org/10.35759/JABs.169.10

\begin{abstract}
Objectives: The study aims to improve traditional livestock production in Maniema province. Specifically, the study consists of collecting data on sheep rearing and determining the appropriate conditions for rearing by rural households. Methodology and Results: A cross-sectional survey was conducted among farmers in Kibombo $(n=80)$, Kailo $(n=10)$ and Kindu $(n=10)$. The age of the herder and the number of ewes per herder were the main criteria for selecting the herders. Statistical analysis was performed using $\mathrm{Ri} 386$ 2.15.0 software. The Fulani breed was the most represented (45\%). With regard to the breeding system, the sheep were raised in the free-range system (85\%). Low values were noted for the free-range system (9\%), the semi-free-range system $(3 \%)$ and the grazing system (3\%). The concept of hygiene and prophylaxis was unknown to many breeders (85\%), as was the mechanisms for managing reproduction $(100 \%)$. The breeding system had a significant influence on prolificity $(\mathrm{p}<0.01)$. The type of shelter was a factor influencing prolificacy $(\mathrm{p}<0.01)$ with better results for the lodge $(1.72 \pm 0.10)$. Prolificity was influenced by density $(\mathrm{p}<0.05)$ with better results for ewes placed in the $1 \mathrm{~m}^{2}$ shelter $(1.54 \pm 0.27)$. Breed was a factor influencing prolificacy $(\mathrm{p}<0.01)$ (Djallonke: 1.25 \pm 0.11 ; Fulani: 1.25 \pm 0.18 ; fat tail sheep: 1.28 \pm 0.17 ; Fulani-Djallonke: $1.36 \pm 0.24)$. Feed intake significantly influenced prolificacy $(\mathrm{p}<0.1)$. Conclusions and application of results: Herd management must be improved to increase prolificacy. It is important to take into account the factors that negatively influence prolificacy. It is important to take into account the factors that negatively influence prolificity, such as shelter, where $62 \%$ of the sheep are raised without shelter, and at the same time, it is necessary to improve the density in the buildings. Similarly, free range grazing should be avoided to mitigate the low prolificacy (1.21 \pm 0.84$)$. To establish a breeding system whose prolificacy would ensure profitability and improve the socio-economic condition of communities living below the poverty line, breeders must consider breeds and feeding.
\end{abstract}

Keywords: breeding system, sheep, prolificity, rural environment, Maniema. 


\section{RÉSUMÉ}

Objectifs: L'étude vise à améliorer l'élevage traditionnel dans la province de Maniema. Spécifiquement, l'étude consiste à collecter des données sur l'élevage des ovins et à déterminer les conditions appropriées pour l'élevage tenu par les ménages ruraux.

Méthodologie et résultats: Une enquête transversale a été menée auprès des éleveurs de Kibombo $(\mathrm{n}=80)$, Kailo $(\mathrm{n}=10)$ et Kindu $(\mathrm{n}=10)$. L'âge de l'éleveur et le nombre de brebis par éleveur ont été les principaux critères de sélection des éleveurs. L'analyse statistique a été réalisée à l'aide du logiciel Ri 386 2.15.0. La race Fulani était la plus représentée (45\%). En ce qui concerne le système d'élevage, les ovins étaient élevés en Divagation (85\%). Des valeurs faibles ont été notées pour la Divagation-bergerie (9\%), la Semi-bergerie (3\%) et l'Herbager (3\%). Le concept d'hygiène et de prophylaxie était inconnu de nombreux éleveurs (85\%), tout comme les mécanismes de gestion de la reproduction $(100 \%)$. Le système d'élevage avait une influence significative sur la prolificité $(\mathrm{p}<0,01)$. Le type d'abri était un facteur influençant la prolificité $(\mathrm{p}<0,01)$ avec de meilleurs résultats pour la loge $(1,72 \pm 0,10)$. La prolificité a été influencée par la densité $(\mathrm{p}<0,05)$ avec de meilleurs résultats pour les brebis placées dans l'abri de $1 \mathrm{~m}^{2}(1,54 \pm 0,27)$. La race était un facteur influençant la prolificité ( $\mathrm{p}<0,01$ ) (Djallonke : 1,25 $\pm 0,11$; Fulani : 1,25 $\pm 0,18$; mouton à queue

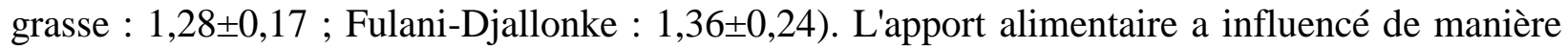
significative la prolificité $(\mathrm{p}<0,1)$.

Conclusions et application des résultats: La gestion du troupeau doit être améliorée afin d'augmenter la prolificité. Il est important de prendre en compte les facteurs qui influencent négativement la prolificité. Il s'agit de l'abri où $62 \%$ des ovins sont élevés sans abri et parallèlement il est nécessaire d'améliorer la densité dans les bâtiments. De même, la divagation doit être évitée pour atténuer la faible prolificité $(1,21 \pm 0,84)$. Pour mettre en place un système d'élevage dont la prolificité assurerait la rentabilité et améliorerait la condition socio-économique des communautés vivant en dessous du seuil de pauvreté, les éleveurs doivent tenir compte des races et de l'alimentation.

Mots clés : système d'élevage, ovin, prolificité, milieu rural, Maniema.

\section{INTRODUCTION}

The breeding system reflects the combination of resources, animal species, and techniques and practices implemented by a community or a breeder to satisfy its needs by valorising natural resources through animals (Lhoste, 2001). The management of animals is an equivocal term, ranging from feeding to breeding, housing, and care. For clarification, it may be grazing management, breeding management, feeding management, and juvenile management. The adaptation of sheep flock management to the risks of drought leads breeders to reflect on production systems and the changes to be considered that will increase the resistance of these systems to hazards in a climate change perspective (Pottier et al., 2007). We can use genetics to exploit differences in performance that may exist between animals maintained under the same conditions (Ministère de la Coopération et du Développement, 1991). To be profitable, sheep must be well managed, and the application of specific management practices must be well reasoned to ensure the flock's well-being. Breeders have had the means to increase the number and weight of lambs marketed annually through advances in breeding management, feeding, and health. (Caron et al., 2007). The improvement of genetic values allows increasing relatively and regularly the average prolificity of ewes (Fathallah, 2015). We can improve this by crossing with a prolific breed or by purebred selection and introducing a major gene, which controls 
prolificity (Sauvant and Martin, 2010). Prolificity is currently the main lever to genetically improve numerical productivity and lambing rate (Martin, 2013). Increasing sheep production consists of improving environmental conditions that participate in the expression of reproductive needs and genetic improvement (Gbangboché et al., 2005). The heritability of prolificity traits in sheep is generally low (0.7-1\%) under the best reproductive conditions, indicating that genetic improvement is not promising, and that improvement of breeding conditions, hygiene, sanitation, feed, and mineral supplementation is more effective (Gbangboché et al., 2002). Proper husbandry would be an asset to raise traditional livestock in the hands of small breeders. The latter has only a small number of livestock, which often roam and are of local breeds that are resistant to disease (Masumbuko et al., 2012). The objective is to improve the traditional type of breeding in the three sites of Maniema Province. Specifically, the study collects data on sheep breeding in the study area and determines adequate breeding conditions by rural households.

\section{MATERIALS AND METHODS}

\section{Study area}

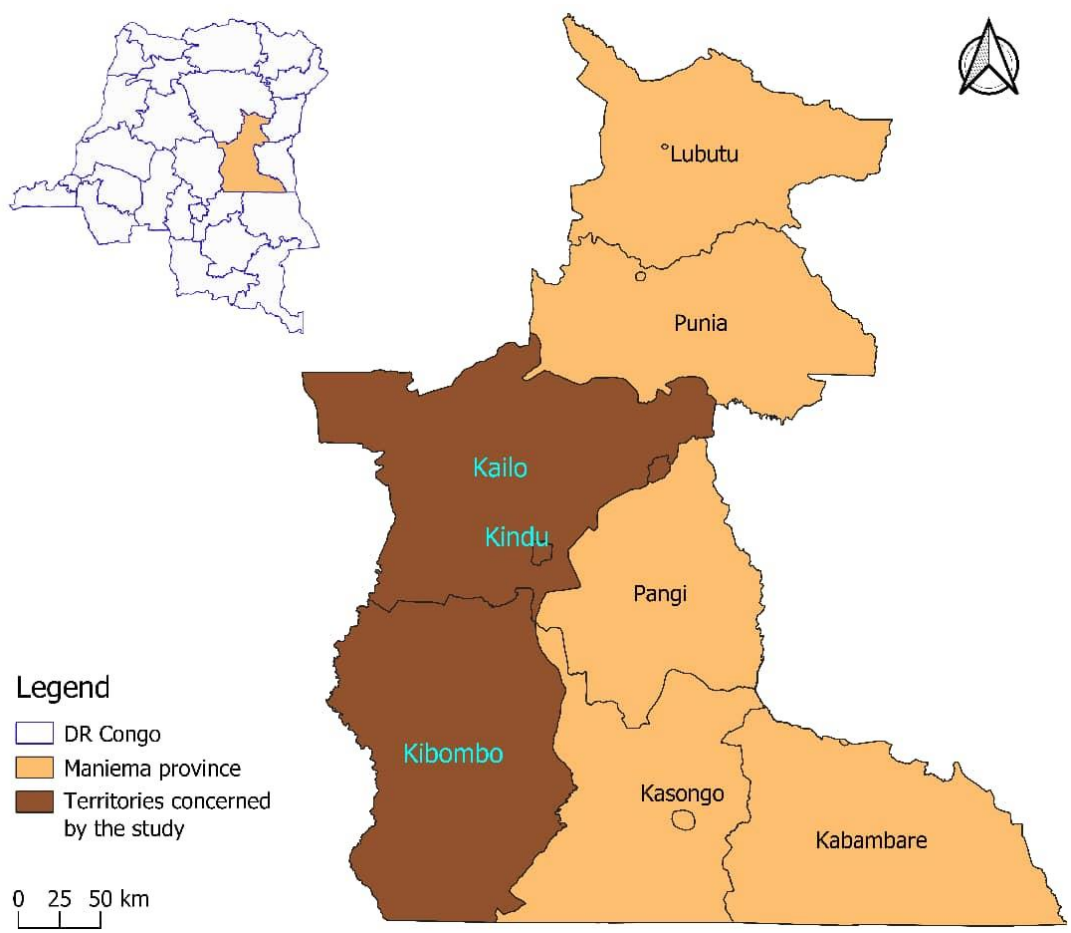

Figure 1: Location of the study area.

The sheep supply flow in the consumption centre had allowed the selection of three sites (Figure 1), namely the Territory of Kibombo (Latitude South 03 $55^{\prime} 22^{\prime \prime}$, Longitude East 025⒌'25", Altitude 500m) with grassy savannahs and forest plains, deciduous forest (Masumbuko et al.,2012); the city of Kailo (Latitude South 2 ${ }^{\circ} 38 ' 58.06 "$ and Longitude
East $26^{\circ} 06^{\prime} 40.59$ ", Altitude $527 \mathrm{~m}$ ) dominated by dense forest and the City of Kindu (Latitude South $0^{\circ}$ and $5^{\circ}$ and $24^{\circ} 55^{\prime}$; Longitude East $28^{\circ} 8^{\prime}$, Altitude $470 \mathrm{~m}$ ) characterized by dense, rainforest. In Maniema, rainfall varies between 1,200 and $1,800 \mathrm{~mm}$. $\mathrm{yr}^{-1}$, with two months of the dry season, one short (mid-January-mid- 
February) and one long (June-August). The average annual temperature is $27^{\circ} \mathrm{C}$.

Animals: A retrospective survey, conducted during 2018-2019, was based on thin-tailed sheep with large (Fulani) and small (Djallonke) and fat tails. Fulani-Djallonke crosses were observed. The cross-sectional survey was conducted between 2017-2018 among breeders in Kibombo Territory $(n=80)$, Kailo City $(n=10)$, and Kindu City $(n=10)$, owning 304 rams and 646 ewes of different ages and 30 lambs born. The age of the breeder and the number of ewes per breeder was the primary criteria for the selection of breeders.

Composition of the survey form: The survey form consisted of the variables and their modalities (Table 1) for 100 breeders randomly selected in the three sites of the province.

Variables retained for the multi-variate analysis and their modalities

Table 1: Variables according to their modalities

\begin{tabular}{l|l}
\hline Variables & Modalities \\
\hline Observed breeds & Thin tail: tall and short \\
Breeding system & Fat tail \\
& Total free-range \\
& Free-range \\
& Semi-free-range \\
Type of shelter & Grazing \\
& Pens \\
& Unsheltered \\
Food supply & Dwelling house \\
Reproductive management & Lodges \\
Hygiene practice & Yes or No \\
Prophylactic practice & Yes or No \\
Number of pups per litter & Yes or No. \\
Number of pup deaths per litter & Yes or No \\
Number of deaths per herd & \\
\hline
\end{tabular}

Each variable has different modalities that express the object that will be measured, notably for the breeds observed, the breeding system, and the type of shelter (pen, no shelter, dwelling house, and lodge). The breeding system practiced by the breeders was traditional or semi-modern (grazing). The conventional system had three modes: total free-range, free-range with a long rambling period, and semi-free-range with a long shepherding period.
Data processing: A semi-open-ended questionnaire was used to collect information on the conduct and system of herding. The number of times or the observed frequency of a data or indicator, presented in percentage, was interpreted, and discussed. Results and field observations were subjected to analysis of variance using $\mathrm{R}$ i386 2.15.0 and Minitab. Tukey HSD was used to differentiate between means and to identify the slightest significant difference. 
RESULTS

Breeders by breed, type of shelter, first lambing, breeding system, and hygiene measures

Table 2: Number of breeders (\%) according to sheep breed, type of shelter and first lambing, breeding system, and hygiene measures

\begin{tabular}{l|l|l|l}
\hline Source of variation & Variants & n & \% \\
\hline Breeds raised & Djallonke & 13 & 13 \\
& Fulani & 45 & 45 \\
& Fulani Djallonke & 26 & 26 \\
Type of shelter & Fat tail & 16 & 16 \\
& Pens & 12 & 12 \\
& Lodges & 10 & 10 \\
& Dwellings & 16 & 16 \\
First lambing & Unsheltered & 62 & 62 \\
& 11 months & 62 & 62 \\
Breeding system & 12 months & 21 & 21 \\
& 13 months & 14 & 14 \\
& $15-16$ months & 3 & 3 \\
& Total free-range & 85 & 85 \\
Hygiene and prophylaxis & Free-range & 9 & 9 \\
Reproduction management & Semi-free-range & 3 & 3 \\
& Grazing & 3 & 3 \\
\hline & Yes & 15 & 15 \\
& No & 85 & 85 \\
\hline
\end{tabular}

The results observed in the three sites showed that the Fulani breed was the highest (45\%), followed by the Fulani-Djallonke breed (26\%), the fat tails (16\%), and the Djallonke (13\%). The age at first lambing was 11 months $(62 \%)$, 12 months (21\%), 13 months (14\%), and 15-16 months (3\%). Most of the sheep were unsheltered (62\%). As for the type of shelter, the sheep were housed in dwellings (16\%), pens $(12 \%)$, or lodges $(10 \%)$. Concerning the breeding system, we kept most of the sheep in Total free-range $(85 \%)$ and a small proportion in Free-range $\quad(9 \%)$, Semi-free-range $(3 \%)$, and Grazing (3\%). Many breeders (85\%) were unfamiliar with the concept of hygiene and disease control. Indeed, very few breeders ensured the hygiene of the buildings (10\%) and the traditional care $(5 \%)$. Breeding management mechanisms were unknown to breeders (100\%) (Table 2).

Prolificity according to breeding systems, breeds, feed intake, density, and type of shelter 
Table 3: Prolificity as a function of breeding systems, breeds, feed intake, density and type of shelter

\begin{tabular}{|c|c|c|c|c|}
\hline Source of variance & Variants & $\bar{n}$ & $\bar{X} \pm \delta$ & Effect \\
\hline \multirow[t]{4}{*}{ Breeding system } & Total free-range & 85 & $1.21 \pm 0.84$ & \\
\hline & Free-range & 9 & $1.61 \pm 0.07$ & $*$ \\
\hline & Semi-free-range & 3 & $1.63 \pm 0.15$ & $*$ \\
\hline & Grazing & 3 & $1.94 \pm 0.11$ & $* *$ \\
\hline \multirow[t]{4}{*}{ Breed } & Djallonke & 13 & $1.25 \pm 0.11$ & \\
\hline & Fulani & 45 & $1.25 \pm 0.18$ & \\
\hline & Fulani-Djallonke & 26 & $1.36 \pm 0.24$ & $*$ \\
\hline & Fat tail & 16 & $1.28 \pm 0.17$ & \\
\hline \multirow[t]{2}{*}{ Food intake } & Yes & 56 & $1.36 \pm 0.22$ & $*$ \\
\hline & No & 44 & $1.17 \pm 0.07$ & \\
\hline \multirow[t]{4}{*}{ Density (m²/head) } & 1 & 16 & $1.54 \pm 0.27$ & $*$ \\
\hline & 0.75 & 7 & $1.37 \pm 0.14$ & \\
\hline & 0.65 & 13 & $1.39 \pm 0.17$ & \\
\hline & 0.50 & 2 & $1.30 \pm 0.00$ & \\
\hline \multirow[t]{4}{*}{ Type of shelter } & Pens & 12 & $1.33 \pm 0.16$ & \\
\hline & Lodges & 10 & $1.72 \pm 0.10$ & $*$ \\
\hline & Dwelling house & 16 & $1.36 \pm 0.12$ & \\
\hline & Unsheltered & 62 & $1.18 \pm 0.07$ & \\
\hline
\end{tabular}

Legend: * significant effect, $* *$ very significant effect

The variability was significant between the means of prolificity observed between the breeding system $(\mathrm{p}<0.01)$. The breeding system had a considerable influence on the prolificity $(\mathrm{p}<0.01)$, and good results were observed with the practice of grazing $(1.94 \pm 0.11)$. The free-range $(1.61 \pm 0.07)$ and the semi-free-range $(1.63 \pm 0.15)$ had comparable results. The total free-range system had a low prolificity $(1.21 \pm 0.84)$. The type of shelter was a factor influencing prolificity $(\mathrm{p}<0.01)$. Indeed, the results were better for the lodge $(1.72 \pm 0.10)$ compared to those related to the types of Dwelling house
(1.36 \pm 0.12$)$, Pen $(1.33 \pm 0.16)$, and Unsheltered $(1.18 \pm 0.07)$. Prolificity was influenced by density $(p<0.05)$ with better results in ewes placed in the shelter with a thickness of $1 \mathrm{~m}^{2}$ (1.54 \pm 0.27$)$ compared to the shelter with a density of less than $1 \mathrm{~m}^{2}$. In addition, the breed was an influencing factor for prolificity. Low values were observed for the Djallonke (1.25 \pm 0.11$)$, Fulani (1.25 \pm 0.18$)$, and fat-tailed sheep $(1.28 \pm 0.17)$ breeds compared to the Fulani-Djallonke $(1.36 \pm 0.24)$. Feed intake significantly influenced prolificity $(\mathrm{p}<0.1)$ (Table 3).

\section{Sheep mortality}


Table 4: Sheep mortality

\begin{tabular}{l|l|l|l}
\hline Sheep & Ages & Number of deaths & \% \\
\hline Born dead & 0 & 70 & 7.14 \\
Lambs & $0-5$ days & 76 & 7.75 \\
& 5 days - 2 months & 49 & 5.00 \\
Sires & Before weaning & 35 & 3.57 \\
& Ewes & 87 & 8.87 \\
Total & Rams & 49 & 5.00 \\
\hline
\end{tabular}

Breeders had recorded losses in stillborn lambs $(\mathrm{n}=70,7.14 \%)$. The lambs showed mortality at different ages, notably at $0-5$ days $(n=76$, $7.75 \%)$, at 5 days -2 months $(n=49,5.0 \%)$ and

\section{DISCUSSION}

Breeders according to breeds raised, type of shelter, first lambing, breeding system, and hygiene measures: Sheep of the Fulani breed more likely to be reared (45\%) compared to other species (Fulani-Djallonke: 26\%, fat tails: 16\%, Djallonke: 13\%) (Table 2). The Congo Dwarf individual is one of the Djallonke strains; the Fulani individual was described as Congo Long-legged and the fat-tailed individual as Ugogo from Tanganyika (Meyer et al., 2004). Age at first lambing was 11 months in a significant proportion of females (62\%). However, variations were observed, namely age at the first lambing of 12 months (21\%), 13 months (14\%), and 15-16 months (3\%) (Table 2). Identical conditions of puberty, occurring at 6 months of age, were observed in females at the end of the work conducted in tropical areas (Ouattara et al., 2021). The age of first lambing, an indicator of sexual precocity, had a positive effect on prolificity. Indeed, the latter was high in late females (Fathallah, 2015). The majority of sheep were unsheltered (62\%). A few breeders had shelters of the Dwelling house (16\%), Pen (12\%), or Lodges (10\%) type (Table 2). Results for sheep in Niger showed a lower proportion than Maniema (44.6\% vs. $62 \%$ ) (Ali et al., 2003). Generally, breeders had shelters that allowed them to place their before weaning $(n=35,3.57 \%)$. As for sires, losses were observed in ewes $(n=87,8.87 \%)$ and rams $(n=49,5.0 \%)$ (Table 4).

animals in traditional sheepfolds that were often too small and insufficiently ventilated (Guingouain, 2017). The breeding system showed most sheep in total free-range (85\%) and a small proportion in free-range (9\%), semi-free-range (3\%), and grazing (3\%) (Table 2 ). In villages in tropical Africa, sheep in traditional breeding was often divagated (Guingouain, 2017). The concept of hygiene and prophylaxis was unknown to many breeders $(85 \%)$. The hygiene of the buildings was ensured by very few breeders $(10 \%)$. The same was true of traditional care $(5 \%)$ (Table 2 ). Work conducted in rural Togo noted that $42 \%$ received assistance from a veterinary officer only once a year (Guingouain, 2017). Breeding management mechanisms were unknown to the herders (100\%) (Table 2). This contributed to increased inbreeding rates in the herds (Youssao et al., 2008).

Prolificity as a function of rearing system, breed, feed intake, density, and type of shelter: The breeding system had good results on prolificacy with the practice of the Grazing system (1.94 \pm 0.11$)$. Fewer prolific results, but comparable, were observed with the method of Free-range (1.61 \pm 0.07$)$ and Semi-free-range $(1.63 \pm 0.15)$. The total free-range practice had a low prolificity (1.21 \pm 0.84$)$ (Table 3$)$. Studies conducted at INRA and in the central and 
northern part of the Massif Central of France confirmed that prolificity differed according to the breeding systems (Benoit and Laignel, 2009). However, the grazing system was more profitable with a high prolificity level (1.74). Also, this profitability was observed on numerical productivity and fertility in favourable and off-season (Benoit and Laignel, 2009). Prolificity results according to the type of shelter were better for the lodge $(1.72 \pm 0.1)$ compared to those related to the Dwelling house $(1.36 \pm 0.12)$, Pen $(1.33 \pm 0.16)$, and Unsheltered (1.24 \pm 0.07$)$ types (Table 3$)$. It was evident from work conducted at INRA in France that environmental improvement was conducive to increased litter size in sheep (Fathallah, 2015). Small ruminants do not cope well with confinement, lack of freedom, and stormy weather that disturb the environment (Meyer et al., 2004). Prolificity showed better results in ewes placed in the shelter at a density of $1 \mathrm{~m}^{2}(1.54 \pm 0.27)$ Low prolificity values were observed for the Djallonke (1.25 \pm 0.11$)$, Fulani (1.25 \pm 0.2$)$, and fat-tailed sheep (1.28 \pm 0.17$)$ breeds compared to the FulaniDjallonke (1.36 \pm 0.24$) \quad$ (Table 3). Investigations conducted in Benin had noted that crossbreeding improved sheep prolificity. Indeed, prolificity was relatively good in Djallonke-Sahelian crossbreds (1.5) compared to that observed in Djallonke (1.17-1.5) and Sahelian (1.25-1.61) (Gbangboché et al., 2002). Feed intake significantly influenced prolificity $(\mathrm{p}<0.01)$ (Table 3$)$. Indeed, poor reproductive performance was a manifestation of poor nutritional status (Gbangboché et al., 2005). Moreover, the best reproductive performances were observed when natural pasture was available in quantity and quality (Kouriba et al., 2004). Finally, it was evident that sheep performance in fattening depended on dietary factors (Pitala et al., 2012).

Sheep mortality: Mortalities were recorded in both stillborn lambs $(n=70,7.14 \%)$, lambs at $0-5$ days $(\mathrm{n}=76,7.75 \%)$, at 5 days -2 months $(\mathrm{n}=49,5.0 \%)$, and before weaning $(\mathrm{n}=35$, $3.75 \%$ ) as well as in sires (ewes: $n=87,8.87 \%$; rams: $n=49,5.0 \%$ ) (Table 4). Different studies have emphasized that malnutrition is a cause of mortality in sheep (6.30-34, 9-51\%) (Kouriba et al., 2004). In addition, poor husbandry system, inadequate husbandry, and lack of care by the herders were held responsible for mortalities (18.0 $\pm 17.56 \%)$ (Djalal, 2011).

\section{CONCLUSION AND APPLICATION OF RESULTS}

The study consisted of collecting data on sheep farming in the study area and determining suitable conditions for livestock keeping by rural households in three sites in Maniema Province. The results indicate that the Fulani breed was the most common (45\%) along with the Fulani-Djallonke $(26 \%)$, the fat-tailed (16\%), and the Djallonke (13\%). The age at first lambing was variable (11 months: 62\%, 12 months: 21\%, 13 months: $14 \%, 15-16$ months: $3 \%$ ). Most of the sheep were unsheltered $(62 \%)$, and the rest were in dwellings (16\%), pens (12\%), or lodges (10\%). Concerning the breeding system, the sheep were kept in total free-range $(85 \%)$, free-range $(9 \%)$, semi-free-range $(3 \%)$, and grazing $(3 \%)$. Many breeders $(85 \%)$ were unfamiliar with the concept of hygiene and prevention. Breeders $(100 \%)$ did not know breeding management mechanisms. The breeding system had a significant influence on prolificity $(\mathrm{p}<0.01)$, and good results were observed with the practice of grazing $(1.94 \pm 0.11)$. The results were similar for the free-range $(1.61 \pm 0.07)$ and semi-free-range $(1.63 \pm 0.15)$ systems. Total free-range had a low prolificity $(1.21 \pm 0.84)$. The type of shelter was a factor influencing prolificity $(\mathrm{p}<0.01)$ with better results for the lodge $(1.7 \pm 0.10)$ compared to those related to the Dwelling house $(1.36 \pm 0.12)$, pen $(1.33 \pm 0.16)$, and unsheltered $(1.18 \pm 0.07)$ types. Prolificity was influenced by density $(p<0.05)$ with better results for ewes placed in the shelter with a thickness of $1 \mathrm{~m}^{2}(1.54 \pm 0.27)$ 
compared to the shelter with a density of less than $1 \mathrm{~m}^{2}$. In addition, the breed was a factor influencing prolificity $(\mathrm{p}<0.01)$. Low values were observed for the Djallonke (1.25 \pm 0.11$)$, Fulani (1.25 \pm 0.18$)$, and fat-tailed sheep (1.28 \pm 0.17$)$ breeds compared to the FulaniDjallonke $\quad(1.36 \pm 0.24)$. Feed intake significantly influenced prolificity $(\mathrm{p}<0.1)$. Mortalities were recorded in stillborn lambs $(\mathrm{n}=70,7.14 \%)$, lambs at $0-5$ days $(\mathrm{n}=76$, $7.75 \%)$, at 5 days -2 months $(\mathrm{n}=49,5.0 \%)$ and before weaning $(\mathrm{n}=35,3.75 \%)$, as well as in the sires (ewes: $n=87,8.87 \%$; rams: $n=49$, 5.0\%): The breeding system and management need to be improved to increase prolificity.

\section{REFERENCES}

Ali L, Van den Bossche P, Thys E, 2003. Enjeux et contraintes de l'élevage urbain et périurbain des petits ruminants à Maradi au Niger: quel avenir? Revue d'élevage et de médecine vétérinaire des pays tropicaux, $\quad 56(1-2): 73-82$. DOI: https://doi.org/10.19182/remvt.9 $\underline{879}$

Benoit M and Laignel G, 2009. Performances techniques et économiques en élevage biologique d'ovins viande: observations en réseaux d'élevage et fermes expérimentales. Elevage bio, INRAE Productions Animales, 22, 3 197-206 https://doi.org/10.20870/productionsanimales.2009.22.3.3346

Caron VD, Pellerin D, Gagnon JM, Rivest S, Benjelloun F, Theriault M, Castonguay F, 2007. Impact de la prolificité sur la rentabilité de l'entreprise ovine Québécoise: approche par modélisation. Journée de Recherche en production ovine, https://ovins.fsaa.ulaval.ca/fileadmin/c entre recherche/publications/documen ts/JRPO2007_Prolif.pdf
The management of the herd needs to be improved to increase the prolificity. It is essential to consider the factors that negatively influence prolificity. It is about the shelter where many sheep are raised without shelter, and concomitantly it is necessary to improve the density in the houses. In addition, total free-range should be avoided to mitigate the low prolificity. To set up a breeding system whose prolificity would ensure profitability and improve the socio-economic condition of communities living below the poverty line, breeders must take into account the breeds and the feeding.

Djalal AK, 2011. Elevage ovin périurbain au Tchad : Effet de l'alimentation sur les performances de reproduction et de croissance. Thèse de Doctorat Unique en Développement Rural. Option : Systèmes Productions Animales. Spécialité : Génétique et Reproduction. Université Polytechnique de BoboDioulasso, Burkina-Faso, http://www.beep.ird.fr/collect/upb/ind ex/assoc/IDR-2011-DJA-ELE/IDR2011-DJA-ELE.pdf

Fathallah S, 2015. Variabilités de la taille de portée des ovins. PhD, Pathologie, Toxicologie, Génétique et Nutrition, Institut National Polytechnique de Toulouse. https://oatao.univtoulouse.fr/19545/

Gbangboché AB, Abiola FA, Laporte JP, Salifou S, Leroy PL, 2002. Amélioration des ovins dans l'Ouémé et le Plateau en République du Bénin. Enjeux de croisement des ovins Djallonké avec les moutons du Sahel. Tropicultura, 20(2), 70-75. http://www.tropicultura.org/text/v20n 2/70.pdf

Gbangboché AB, Hornick JL, AdamouN'diaye M, Edorh AP, Farnir F, Abiola 
FA, Leroy PL, 2005. Characterisation and control of the reproduction and growth parameters of Djallonke ovines (Ovis amon aries). Annales de Médecine Vétérinaire, 149 (3), 148160

Guingouain LN, 2017. Élevages des petits ruminants en milieu paysan dans les régions de la Kara et des savanes au Togo : diagnostic technicoéconomique. Thèse. École Nationale Vétérinaire d'Alfort.

Kouriba A, Nantoumé H, Togola D, 2004. Caractères de reproduction et mortalité des jeunes moutons Toronké à la station de recherche zootechnique de Kayes. Tropicultura, 22 (3) : 134-138. http://www.tropicultura.org/text/v22n 3/134.pdf

Lhoste $\mathrm{Ph}, 2001$. L'étude et le diagnostic des systèmes d'élevage. Atelier de formation des agronomes SCV Madagascar, https://www.docdeveloppementdurable.org/file/Elevages/VachesLaiti eres/etude\%20\&\%20diagnostic\%20de s\%20systemes\%20d-elevage.pdf

Martin P, 2013. Analyse du gène Lacaune d'hyperprolificité dans la population Lacaune Viande OviTest. Sciences agricoles.

https://dumas.ccsd.cnrs.fr/dumas00913211/document

Masumbuko CK, Makuta MC, Ntamwira N, 2012. Enquête socio-économique dans les bassins de production agricole du PIRAM dans la Province du Maniema en RD Congo Décembre 2012. https://hal-auf.archivesouvertes.fr/hal-00871281/document.

Meyer C, Faye B, Karembe H, Poivey JP, Deletang F, Hivorel P, Benkirane A, Berrada J, Mohammedi D, Gharzouani S, 2004. Guide de l'élevage du mouton méditerranéen et tropical. CEVA Santé animale-CIRAD-EMVT, 166 p. https://www.doc-developpementdurable.org/file/Elevages/MoutonsOvins/Guide_Mouton_121103.pdf

Ministère de la Coopération et du Développement, 1991. Mémento de l'agronome. $4^{\text {ieme }} \mathrm{Ed}$, Collection Techniques rurales en Afrique https://horizon.documentation.ird.fr/ex 1-doc/pleins textes/divers2008/34646.pdf

Ouattara O, Aboubacrine MT, Konaté D, Sognan D, Diakaridia T, 2021. Morphological characteristics of indigenous Djallonké sheep in rural areas in the south of Mali. International Journal of Livestock Production, 12(3) ,128-139. https://doi.org/10.5897/IJLP2021.0763

Pitala W, Yaokorin Y, Bonfoh B, Boly H, Gbeassor M, 2012: Évaluation de la réponse du mouton Djallonké à l'embouche herbagère à Kolokopé au Togo. Livestock Research for Rural Development. Volume 24, Article \#5. Retrieved September 22, 2021, from http://www.lrrd.org/lrrd24/1/pita2400 $\underline{5 . h t m}$

Pottier E, Delaby L, Agabriel J, 2007. Adaptations de la conduite des troupeaux bovins et ovins aux risques de sécheresse. Fourrages, Association Française pour la Production Fourragère, 191, 267-284. https://hal.inrae.fr/hal02655853/document

Sauvant D and Martin O, 2010. Robustesse, rusticité, flexibilité, plasticité, résistance....Les nouveaux critères de qualité des animaux et des systèmes d'élevage. Dossier, Robustesse, rusticité, flexibilité, plasticité... les nouveaux critères de qualité des animaux et des systèmes d'élevage : définitions systémique et biologique des différents concepts INRAE Productions animales, 23(1) 5-10 DOI 
: https://doi.org/10.20870/productionsanimales.2010.23.1.3280

Youssao AKI, Farougou S, Koutinhouin BG, Bio Bagou G, Kora BD, 2008. Aptitudes maternelles de la brebis Djallonké en élevage traditionnel dans la Commune de Banikoara au Bénin. Revue de Médecine Vétérinaire 159 (11), 538-544. https://www.researchgate.net/profile/S ouaibou-

Farougou/publication/234081314_Apt itudes_maternelles_de_la_brebis_Djal lonkeen_elevage traditionnel_dans_la _Communede_Banikoara_au_Benin/li nks/0fcfd50f59b9b5cf8d000000/Aptit udes-maternelles-de-la-brebisDjallonke-en-elevage-traditionneldans-la-Commune-de-Banikoara-au$\underline{\text { Benin.pdf }}$ 